\title{
Overview of Gadget Utilization and Its Effect on Growth and Development in Preschool Children
}

\author{
Rini Andriani \\ Departement of Child Health, Faculty of Medicine, Universitas Tanjungpura, Pontianak, West Kalimantan, Indonesia
}

\begin{abstract}
DATA OF ARTICLE:
Received: 05 Apr 2021

Reviewed: 20 Apr 2021

Revised: 06 July 2021

Accepted: 05 Nov 2021

CORRESPONDENCE:

rini@medical.untan.ac.id

DOI:

10.18196/mmjkk.v21i2.11435

Abstract: The gadget utilization among preschoolers in connection with technological advances is known to have positive and negative effects on growth and development. This study aims to identify the overview of gadget utilization and its effect on growth and development in preschool children. An analytic survey with a cross-sectional design was conducted by filling out questionnaires carried out by parents. The anthropometric measurements and developmental assessments were carried out using Indonesia Developmental Pre-screening Questionnaire (IDPQ). A hundred children and their parents participated in this study. It was found that $82 \%$ of parents lent their gadgets, and $89 \%$ taught their children to use gadgets. There were similarities in gadget utilization between parents and children, namely watching videos (73\% and $90 \%)$ and communicating ( $92 \%$ and $40.4 \%$ ). The duration of the gadget utilization by children

TYPE OF ARTICLE: was high, $3.7 \pm 2.2$ hours/day. However, no significant correlation in the analysis between the duration of smartphone usage and nutritional status (p: 0.599). In children with different IDPQ values, there was no significant difference in the duration of device usage (p: 0.991). It can concluded the duration of the gadget utilization in children carried out by their parents did not affect the growth and development of the children.
\end{abstract}

Keywords: Development; Gadgets; Growth; Preschool Children

\section{INTRODUCTION}

The use of gadgets is a necessity in this era of globalization. Gadgets are widely used in various fields, including education. In general, gadgets are used to communicate, find information about various things, as well as entertainment and games. Current gadget users include all ages, young and old, including teenagers (12-20 years), school children (6-12 years) and even preschool children (2-6 years) .,2 A gadget is a small and practical electronic device with a special function and is designed with sophisticated technology, such as laptops, handphones or smartphones, notebooks, and tablets/iPad. ${ }^{3}$ Gadgets are also defined as electronic devices that have certain practical purposes and functions, especially to help and facilitate human work. ${ }^{3,4}$

The age of preschool children is the age where the process of child development continues after the golden period in the first 1000 days of life (from conception to the age of 2 years); thus, this phase is also very important for the basis of subsequent child development. ${ }^{5} 6$ Preschool age is children aged three to six years, but currently, many children have started school at the age of 2 years to accelerate the introduction of the environment and socialization as well as increasing the stimulation to children, especially for children whose parents both work. ${ }^{1,2}$

Growth, which includes increased body weight, height and head circumference, will run simultaneously with basic development such as gross motor skills, fine motor skills, speech, and social personality. The growth of a child can be assessed using existing growth curves, such as the growth curves from the WHO and CDC. ${ }^{7}$ As for the development of a child, it can be assessed using various developmental screening tools available for various ages, such as Indonesia Developmental Pre-Screening Questionnaire (KPSP), Denver II test, The Bayley Scales of Infant and Toddler Development / Bayley III, and many more that can be used according to the age of the child being tested for development. ${ }^{8}$

Global developmental delay is a state of significant developmental delay in two or more developmental domains. About 5 to $10 \%$ of children are estimated to have developmental delays. The biggest 
complaint about the delay in global development is "not walking and talking". The data on the incidence of general developmental delays are not known with certainty, but it is estimated that about $1-3 \%$ of children under 5 years of age experience general developmental delays.9, 10 In Indonesia, the development index of children aged 36-59 months for literacy aspect is $64.6 \%$, the physical aspect is $97.8 \%$, social-emotional aspect is $69.9 \%$, and learning aspect is $95.2 \%$; thus, the total development index of Indonesia in 2018 was $88.3 \%{ }^{11}$

The data of Pelangi Kasih Growth and Development clinic in Pontianak City from 2013-2017, with a total of 302 visits, found that the main complaint was speech delay (80.8\%) and the most common age of children who were brought for development consultation was 40 months old even though the parents had worried about the existence of developmental disorders from the age of 21 months, where the age of 40 months is the age of preschool children. ${ }^{12}$ Research by Tjandrajani et al. stated that speech delay is a common delay in children aged $2-5$ years and found $46.8 \%$ of speech disorders in children with general developmental delays. ${ }^{13}$

The most common etiologies of developmental delay are cerebral dysgenesis, cerebral palsy, TORCH infection, genetic syndromes, and endocrine metabolic disorders..$^{10}$ Recently, excessive use of gadgets was found to cause physical growth and development disorders in children, such as gross motor development, fine motor skills, language speaking, personal social interaction, emotional, mental, and academic achievement. ${ }^{14,15}$ Physical disorders that can occur are in the form of growth disorders, such as malnutrition or overnutrition was caused by undisciplined eating and drinking patterns, limited movement, and excessive sensory stimulation and sleep disturbances. ${ }^{9}$

The use of gadgets, especially handphones, continues to increase in children aged 0-8 years. In 2011, $52 \%$ of children aged $0-8$ had access to a gadget, increasing to $75 \%$ in 2013 . On average, children aged $3-8$ use a gadget for 1 hour or more per usage at a time. ${ }^{1,16}$ Preschool children are frequently allowed to use gadgets by their parents as a medium to provide education to children. However, in its use, children often use gadgets for entertainment such as playing games, which in turn causes them to lose their desire to interact socially with the environment as they are more interested in the gadgets. ${ }^{14,17,18}$ According to the 2017 Information and Communication Technology (ICT) Utilization Survey, $15.3 \%$ respondents aged $9-19$ years old were found with an education level of $23 \%$ for elementary school, $24 \%$ for junior high school, and $39 \%$ for high school. ${ }^{19}$ Another study found that 98 percent of children and adolescents (10-19 years) knew about the internet and that 79.5 percent of them were internet users. ${ }^{20}$ However, until now, there has been no data on the use of ICT equipment by preschool children.

There is a considerable amount of debate about the effects of using gadgets on children, especially preschoolers who are still in a rapid phase of growth and development. Excessive gadget utilization in preschool children can cause obesity due to a sedentary lifestyle, inhibiting children's ability to interact with people around them, leading to developmental disorders such as delays in expressive speech. ${ }^{15},{ }^{21-23}$ The introduction of gadgets is expected to introduce many new technologies as well as new educational and teaching methods to children. However, a good introduction process and adequate monitoring from parents must be made a guideline so that the positive impact obtained by the child exceeds the negative impact that may arise from the use of this device.

In a 2015 study by Trinika et al. on 166 children in Kindergarten at a school in Pontianak City, it was found that there was an effect of using gadgets on the psychosocial development of preschoolers (3-6 years), where it was found that children preferred to play with gadgets compared to playing with their peers. Specifically, this study found that preschoolers use gadgets for about half to 5 hours per day. ${ }^{24}$ However, this study only assessed psychosocial development without other developmental domains. Based on this background, the researcher considered it is important to conduct research on the overview of gadget utilization and its effect on growth and development, including gross motor, fine motor, language speech, and personal social domain in preschool children in Kindergarten in Pontianak.

\section{MATERIALS AND METHOD}

This research was an analytical survey using a cross-sectional design intended to identify the correlation between variables. This research was conducted from April to August 2018 in Kindergarten in Pontianak city. The population in this study were preschool children of 2-6 years old in kindergarten in Pontianak city, while the subjects in this study were preschoolers of 2-6 years old in kindergarten in Pontianak city who met the research criteria with their parents. The sample in this study was taken with probability sampling, namely cluster sampling.

This research instrument used primary data with data collection methods using a questionnaire as a measuring tool. The parents of the preschool children were requested to fill out a questionnaire, which 


\section{mutiara
medika}

consisted of parents' data (age, education, occupation, and income), the introduction of gadgets, ownership of gadgets, duration of using gadgets, and usage of gadgets). The gadgets in this study included handphones/smartphones, laptops, notebooks, and tablets / iPad.

In preschool children, measurements of body weight, height and circumference of the head were carried out by a research team trained on measuring children's anthropometry when the parents filled out the questionnaire. The child's nutritional status was determined by plotting the child's anthropometric values (weight, height) on the WHO curve. The assessment of child development was carried out using the Indonesian Developmental Pre-Screening Questionnaire (IDPQ) at the same time as the anthropometric data were collected. The KPSP tools used in this study had been widely used in Indonesia as a screening tool in assessing child development, with a sensitivity of $95 \%$. The researchers worked with the same team of field research officers to collect data in three different schools in different regions. This research was conducted after passing the ethical review No. 4230 / UN22.9 / DT / 2017.

The data processing was carried out using a computer through editing, coding, data entry or data processing and cleaning with the Statistical Products and Service Solutions (SPSS) computer program for Windows20.

\section{RESULTS}

The subjects were 100 children and their respective parents ( 59 boys and 41 girls). The sample age group was divided into 3 groups, namely $<3$ years as many as 9 children (9\%), 3-4 years as many as 36 children (36\%), and 5-6 years as many as 55 children (55\%). The description of the characteristics of the subject's father and mother can be seen in Table 1. The average of the children was $45.9 \pm 10.4$ months. Meanwhile, the mean age of the subject's father and mother were $35.0 \pm 4.2$ years and $32.1 \pm 3.1$ years, respectively.

Table 1. Subject Characteristics (Children and Parents)

\begin{tabular}{|c|c|c|}
\hline Characteristics & Total & Percentage (\%) \\
\hline \multicolumn{3}{|c|}{ Children's caretaker(n=100) } \\
\hline Parent & 100 & 100 \\
\hline \multicolumn{3}{|l|}{ Maternal education } \\
\hline $\begin{array}{l}\text { Junior High School } \\
\text { Senior High School } \\
\text { Diploma } \\
\text { Undergraduate } \\
\text { Postgraduate }\end{array}$ & $\begin{array}{c}2 \\
32 \\
18 \\
45 \\
3\end{array}$ & $\begin{array}{c}2 \\
32 \\
18 \\
45 \\
3\end{array}$ \\
\hline \multicolumn{3}{|l|}{ Maternal job } \\
\hline $\begin{array}{l}\text { Housewife } \\
\text { Government employee } \\
\text { Private employee } \\
\text { Entrepreneur } \\
\text { Etc. }\end{array}$ & $\begin{array}{c}75 \\
5 \\
10 \\
8 \\
2\end{array}$ & $\begin{array}{c}75 \\
5 \\
10 \\
8 \\
2\end{array}$ \\
\hline \multicolumn{3}{|l|}{ Paternal education } \\
\hline $\begin{array}{l}\text { Junior High School } \\
\text { Senior High School } \\
\text { Diploma } \\
\text { Undergraduate } \\
\text { Postgraduate }\end{array}$ & $\begin{array}{c}2 \\
34 \\
19 \\
40 \\
5\end{array}$ & $\begin{array}{c}2 \\
34 \\
19 \\
40 \\
5\end{array}$ \\
\hline \multicolumn{3}{|l|}{ Paternal job } \\
\hline $\begin{array}{l}\text { Government employee } \\
\text { Private employee } \\
\text { Entrepreneur } \\
\text { Etc. }\end{array}$ & $\begin{array}{c}4 \\
23 \\
63 \\
10\end{array}$ & $\begin{array}{c}4 \\
23 \\
63 \\
10\end{array}$ \\
\hline
\end{tabular}

The examination of the nutritional status of the subject was carried out by direct measurement of weight and height of the children 3 times at the same time, and the average value obtained was taken, then 
the results were plotted on the WHO curve. The WHO curve of weight-for-height was found in the normal category as many as 63 subjects ( $73.3 \%)$, followed by overnutrition and obesity in 22 subjects $(25.6 \%)$. In the KPSP examination carried out on children, it was found that $67 \%$ of children had developed according to their age, $8 \%$ of children with developmental disorders and as many as $25 \%$ of children with questionable developmental results. The distribution of children's nutritional status based on the curve and the distribution of developmental disorders and based on the developmental domains divided into the gross motor, fine motor, language speech, and personal social can be seen in Table 2.

Table 2. Distribution of subjects according to the nutritional status of subjects and status of development

\begin{tabular}{|c|c|c|}
\hline Nutritional status and development & Total & Percentage \\
\hline \multicolumn{3}{|c|}{ Nutritional Z-Score Weight for Height $(n=86)$} \\
\hline Wasting & 1 & $1.2 \%$ \\
\hline Normal & 63 & $73.3 \%$ \\
\hline Overweight & 16 & $18.6 \%$ \\
\hline Obesity & 6 & $7.0 \%$ \\
\hline \multicolumn{3}{|l|}{ Nutritional BMI/age ( $n=14)$} \\
\hline Overweight & 4 & $71.4 \%$ \\
\hline Normal & & \\
\hline \multicolumn{3}{|l|}{ Nutritional Z-Score Weight for age } \\
\hline Normal & 78 & $78.0 \%$ \\
\hline Moderate underweight & 20 & $20.0 \%$ \\
\hline Severe underweight & 2 & $2.0 \%$ \\
\hline \multicolumn{3}{|l|}{ Nutritional Z-Score Height for age } \\
\hline Normal & 94 & $94.0 \%$ \\
\hline Stunting & 6 & $6.0 \%$ \\
\hline \multicolumn{3}{|l|}{ Gross motor development } \\
\hline Interference was found & 16 & $16.0 \%$ \\
\hline No interference was found & 84 & $84.0 \%$ \\
\hline \multicolumn{3}{|l|}{ Fine motor development } \\
\hline Interference was found & 5 & $5.0 \%$ \\
\hline No interference was found & 95 & $95.0 \%$ \\
\hline \multicolumn{3}{|l|}{ Language development } \\
\hline Interference was found & 13 & $13.0 \%$ \\
\hline No interference was found & 87 & $87.0 \%$ \\
\hline \multicolumn{3}{|l|}{ Autonomy development } \\
\hline Interference was found & 22 & $22.0 \%$ \\
\hline No interference was found & 78 & $78.0 \%$ \\
\hline \multicolumn{3}{|l|}{ KPSP Development } \\
\hline Deviation & 8 & $8.0 \%$ \\
\hline Dubious & 25 & $25.0 \%$ \\
\hline None interference & 67 & $67.0 \%$ \\
\hline
\end{tabular}

Based on the results of filling out the questionnaire by the parents, it was found that most of the gadgets were available at home ( $92 \%$ of respondents) and that most of the gadgets used by children were borrowed by their parents ( $82 \%$ ) and only about $10 \%$ were purchased devices by their parents. Parents were the trainers for gadgets for their children (89\%), and only about $11 \%$ knew gadgets from other families or schools.

There is a similarity in using gadgets between parents and children, namely watching videos ( $73 \%$ of parents and $90 \%$ of children) and communicating (92\% of parents and $40.4 \%$ of children). However, there is a major difference in parents using gadgets for work (51\%) and children playing games (53\%). The comparison of the use of devices for children and parents can be seen in Figure 1. 


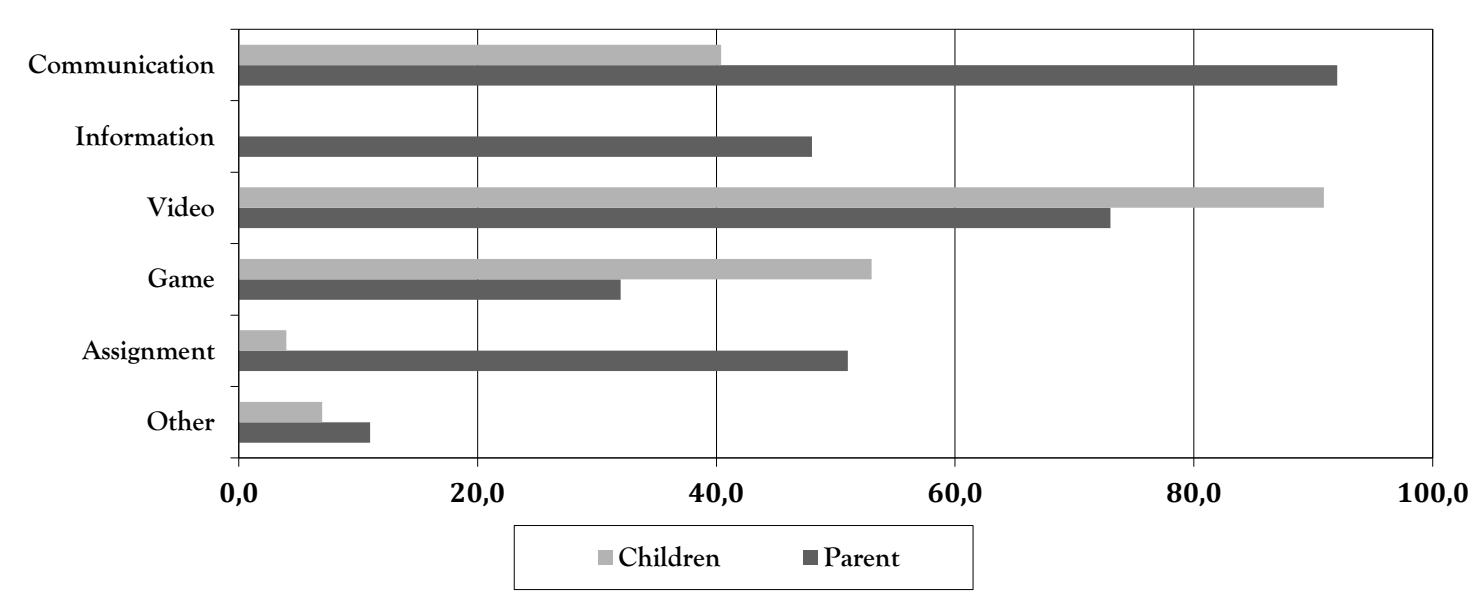

Figure 1. Utilization of Gadgets in Children and Parents

The average duration of children's gadgets was 3.7 hours/day with an SD value of 2.2, and the child's longest use of the device was 10 hours/day. In children with different KPSP results, there was no

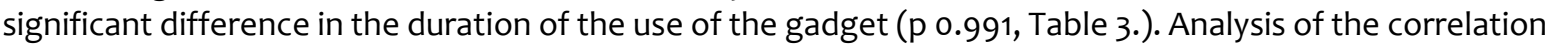
between nutritional status and the usage duration of the gadget by the children did not find a significant correlation ( $p$ 0.599). Furthermore, in the analysis of the correlation between the nutritional status of children and the results of the KPSP examination, no significant correlation was found (Table 4).

Table 3. Variable usage duration of the gadget (hour / day)

\begin{tabular}{lllllll}
\hline Variables & Mean & SD & Median & Min & Max & P value * \\
\hline Deviation & 3.55 & 2.11 & 3.00 & 0.42 & 7.00 & \\
Dubious & 3.73 & 2.55 & 3.50 & 0.00 & 9.00 & 0.991 \\
No interference & 3.67 & 2.14 & 3.00 & 0.50 & 10.00 & \\
\hline
\end{tabular}

Note: *Kruskal Wallis rank test

Table 4. Distribution of subjects according to nutritional status and development of KPSP

\begin{tabular}{|c|c|c|c|c|c|}
\hline \multirow{2}{*}{ Risk Factors } & \multicolumn{3}{|c|}{ KPSP Development } & \multirow[t]{2}{*}{ Total } & \multirow[b]{2}{*}{$\mathrm{p}$-value } \\
\hline & Conform & Dubious & Deviate & & \\
\hline \multicolumn{6}{|l|}{ Nutritional status of weight for age } \\
\hline Normal & 52 & 21 & 5 & 78 & \multirow{3}{*}{0.103} \\
\hline Moderate underweight & 15 & 3 & 2 & 20 & \\
\hline Severe underweight & 0 & 1 & 1 & 2 & \\
\hline $\begin{array}{l}\text { Nutritional status of weight for } \\
\text { height } \\
\text { Wasting-Normal } \\
\text { Overweight-Obesity }\end{array}$ & $\begin{array}{l}43 \\
24\end{array}$ & $\begin{array}{l}20 \\
5\end{array}$ & $\begin{array}{l}5 \\
3\end{array}$ & $\begin{array}{l}68 \\
32\end{array}$ & 0.599 \\
\hline
\end{tabular}

\section{DISCUSSION}

Gadgets are electronic devices that have practical purposes and functions, especially to assist and facilitate human work. The categories of gadgets that are often found in Indonesia are smartphones, handphones, tablets, and computers. ${ }^{3}$

The use of gadgets nowadays can no longer be avoided; therefore, the role of parents and adults in taking care of children is very important. According to The Asian Parent Insights survey in the Southeast Asia region, in 5 countries, namely Singapore, Thailand, Philippines, Malaysia, and Indonesia, most parents allowed gadgets for their children where $77.0 \%$ of parents monitored what a child consumed and saw on their device. Only $11.0 \%$ allowed other family members to monitor their children's gadgets, while $2 \%$ did not monitor the use of children's gadgets at all. Parents in Thailand are the biggest percentage of parents' monitoring of gadgets use (89.0\%), while parents in Singapore have the least monitors $(74.0 \%) .{ }^{16}$ Research by Yulia at Immanuel Christian Kindergarten, Pontianak, found that $97.65 \%$ of students aged 3-6 years used gadgets with gadget usage duration ranging from 30 minutes to 5 hours per day. ${ }^{24}$ 
Parents play an important role in the growth and development of children. In using children's gadgets, parents play a role in monitoring, guiding, and directing. It is hoped that the implementation of this role will remain under the supervision of parents so that the duration and content accessed on the internet /social media through gadgets are appropriate to the children's age and have a positive impact on the children's growth and development. The results showed similarity in the usage of gadgets by parents and children, namely watching videos (73\% of parents and $90 \%$ of children) and communicating ( $92 \%$ of parents and $40.4 \%$ of children). However, there is a major difference in parents using gadgets for work (51\%) and children playing games (53\%). The usage of the gadgets as game media and video media players between parents and children had similar percentage values that showed most parents accompanied their children when using the gadgets.

Gadgets have a positive impact on children's growth and development. Gadgets can be used as a physical skill training tool for fine motor skills (small muscles such as wrists, fingers, feet, lips and tongue) at an early age. ${ }^{25,26}$ As early childhood plays on smartphones or tablets and other gadgets, they will learn to coordinate finger movements and use their hands more quickly and efficiently. Information processing, memory abilities, simple reasoning, and communication of children can also develop through gadgets. ${ }^{25,} 26$ When children play games available on the device, the child's brain will think and process information and continue to analyze. Children can also learn new knowledge from their learning of various pictures, writing, and colors. Games can also train their mentality and attitude towards competition. ${ }^{26}$ Children will be familiar with the terms win and lose when playing games, introducing them to difficulties and effort. Children are expected to be more enthusiastic about getting the desired results through their efforts.

However, gadgets also harm children's growth and development. Children can become addicted to the use of gadgets, so that the length of the screen time causes children's physical activity to be reduced. Inadequate physical activity can increase the risk of obesity in children. ${ }^{26-28}$ In addition to the increased risk of obesity, developmental disorders can also form. Radiation from gadgets can interfere with children's eye health. Children's concentration can also be disturbed, causing delays in understanding lessons. ${ }^{25}, 26$ According to research conducted by Roopadevi et al. (2020), 30\% of 240 preschool children were sleepy during the day, and there was a correlation between device use and children's personal and social development ( $p$ 0.022), in where $11.7 \%$ experienced delays. ${ }^{29}$ Yuniarti et al. also stated that parents were expected to be more selective in granting permission to use gadgets because the majority (56.7\%) of preschool-aged children experienced dubious development, with the Chi-Square results showing a p-value of 0.008 , which indicated that there was a correlation between the duration of the use of the gadgets and the development of the child. ${ }^{21}$

The results of the KPSP study found that $67 \%$ of the subjects were categorized as having no disorders. In addition, there was no difference between the ownership of a child's gadgets and the KPSP results category.

Based on the data on the distribution of gadgets used by parents and children in this study, it is determined that most of the parents accompanied their children when using the gadgets. It can be seen from the similar proportion of using gadgets to watch videos and communicate with parents and children. In addition, it is also known from the existence of $82 \%$ of parents who lent gadgets to their children, and there were $89 \%$ of parents who taught their children using gadgets. The use of gadgets in preschool children under the supervision and control of parents can minimize negative impacts. It is in line with research by Gusti Ayu and $\mathrm{Ni}$ Nyoman ${ }^{30}$ stating that there was a significant correlation between parental guidance on speech and language development of early childhood; that is, almost all subjects who received parental guidance experienced normal development. Furthermore, Laini et al. ${ }^{31}$ stated that there was a correlation between the use of gadgets and the interaction of parents on children's prosocial behavior, where the child's prosocial behavior was better for parents who involved themselves in the use of children's gadgets.

The total duration of gadgets use in one day is categorized into two, namely light user ( $\leq 2$ hours) and heavy user ( $>2$ hours) in several previous studies. ${ }^{17,32,33}$ The average duration of gadgets use by preschool children in this study included in the category of heavy user ( 3.7 hours/day) with usage duration ranging from 0 hours/day to 10 hours/day. Tanjung et al. ${ }^{23}$ stated that preschool children with a high duration usage of gadgets have a risk of obesity by 1.3 times. However, in this study, there was no significant correlation between the duration of the use of the device and the nutritional status of the child.

\section{CONCLUSION}

The duration of the gadget utilization in children carried out by their parents did not affect the growth and development of the children. 


\section{mutiara medika

\section{CONFLICT OF INTEREST}

There is no conflict of interest.

\section{REFERENCES}

1. Ameliola S, Nugraha H. Perkembangan media informasi dan teknologi terhadap anak dalam era globalisasi. In: Moeliono I, Universitas Indonesia. Fakultas Ilmu Pengetahuan B, editors. Proceeding International Conference on Indonesian Studies : ethnicity and globalization / editor, Irmayanti Moeliono. Depok: Fakultas Ilmu Pengetahuan Budaya, Universitas Indonesia; 2013.

2. Hsin C-T, Li M-C, Tsai C-C. The Influence of Young Children's Use of Technology on Their Learning: A Review. Educational Technology $\mathcal{E}$ Society. 2014;17:85-99.

3. Hariyanto KD, Naryoso A. Pengaruh intensitas mengakses fitur-fitur gadget dan tingkat kontrol orang tua terhadap kesehatan mental remaja. Interaksi Online. 2016;4(2):12.

4. Iswidharmanjaya D, Agency B. Bila si kecil bermain gadget: Panduan bagi orang tua untuk memahami factor-faktor penyebab anak kecanduan gadget. Bogor: Bisakimia; 2014.

5. Soetjiningsih, Gde Ranuh IN. Tumbuh Kembang Anak Edisi 2. Jakarta: EGC; 2013.

6. Kliegman R, Behrman R, Nelson W. Nelson textbook of pediatircs. Philadepia: Elsevier; 2016.

7. Grummer-Strawn LM, Reinolf C, Krebs NF. Use of World Health Organization and CDC Growth Charts for Children Aged 0-59 Months in the United States. MMWR. 2010;59(09):1-15.

8. Aisah S, Siregar KN. The cognitive screening in chlidren under five years old in developing countries: a systemtic literature review. Proceedings of International Conference on Applied Science and Health. 2018;3:218-27.

9. Medise BE. Mengenal keterlambatan perkembangan umum pada anak: IDAI; 2013 [Available from: https://www.idai.or.id/artikel/seputar-kesehatan-anak/mengenal-keterlambatan-perkembangan-umumpadaanak\#: : :text=Keterlambatan\%20perkembangan\%20umum\%20atau\%20global,\%2C\%20dan\%20pers onal\%20sosial\%20\%2F\%20kemandirian.

10. Suwarba IGN, Widodo DP, Handryastuti RAS. Profil klinis dan etiologi pasien keterlambatan perkembangan global di Rumah Sakit Cipto Mangunkusumo Jakarta. Sari Pediatri. 2008;10:255-61. http://dx.doi.org/10.14238/sp10.4.2008.255-61

11. Tim Riskesdas 2018. Laporan Nasional Riskesdas 2018. Jakarta: Badan Penelitian dan Pengembangan Kesehatan; 2018.

12. Andriani R. Karakteristik Anak Berkebutuhan Khusus di Klinik Tumbuh Kembang Pelangi Kasih, Pontianak, Tahun 2013-2017. J Indon Med Assoc. 2019;69(6):218-24.

13. Tjandrajani A, Dewanti A, Burhany A, Widjaja J. Keluhan utama pada keterlambatan perkembangan umum di klinik khusus tumbuh kembang RSAB Harapan Kita. Sari Pediatri. 2012;13(6):373-7. http://dx.doi.org/10.14238/sp13.6.2012.373-7

14. Rowan C. A research review regarding the impact of technology on child development, behavior, and academic performance.: Zone'in; 2018 [Available from: http://www.zonein.ca/zoneinworkshop/factsheet/zonein-fact-sheet/.

15. Madigan S, Browne D, Racine N, Mori C, Tough S. Association Between Screen Time and Children's Performance on a Developmental Screening Test. JAMA Pediatrics. 2019;173(3):244-50. https://doi.org/10.1001/jamapediatrics.2018.5056

16. Samsung Kidstime. Mobile device usage among young kids: A Southeast Asia study. Singapore: Tickled Media Pte Ltd; 2014.

17. Council on Communications and Media. Children, Adolescents, and the Media. Pediatrics. 2013;132(5):95861. https://doi.org/10.1542/peds.2013-2656

18. Common Sense Media. Zero to Eigth: Children's Media Use in America 2013. Common Sense Media; 2013.

19. Kementerian Komunikasi dan Informatika Republik Indonesia. Survey Penggunaan TIK 2017 Serta Implikasinya Terhadap Aspek Sosial Budaya Masyarakat. Jakarta: Pusat Penelitian dan Pengembangan Aplikasi Informatika dan Informasi dan Komunikasi Publik; 2017.

20. Gayatri G, Rusadi U, Metningsih S, Mahmudah D, Sari D, Kautsarina., et al. Digital Citizenship Safety among Children and Adolescents in Indonesia. Jurnal Penelitian dan Pengembangan Komunikasi dan Informatika. 2015;6(1):1-16.

21. Yuniarti, Burhan R, Yorita E, Lagora R, Dewi I, editors. Use of gadget duration and development of preschool children in Bengkulu City 2018. 1st International Conference on Inter-professional Health Collaboration (ICIHC 2018); 2018; Bengkulu: Atlantis Press; 2019. 
22. Calorina L, Pawito, Prasetya H. The Effect of Gadget Use on Child Development: A Path Analysis Evidence from Melawi, West Kalimantan. Journal of Maternal and Child Health 2020;5(1):110-9. https://doi.org/10.26911/thejmch.2020.05.01.12

23. Tanjung F, Huriyati E, Ismail D. Intensitas penggunaan gadget dan obesitas anak prasekolah. BKM Journal of Community Medicine and Public Health. 2017;33(12):789-804.

24. Trinika Y, Nurfianti A, Abror I. Pengaruh penggunaan gadget terhadap perkembangan psikososial anak usai prasekolah (3-6 tahun) di TK Swasta Kristen Immanuel tahun ajaran 2014-2015. Jurnal Proners. 2015;3(1):19. http://dx.doi.org/10.26418/jpn.v3i1.11001

25. Sihura F. The Role of Parents "Generation of Z" to the Early Children in the Using of Gadget. Advances in Social Science, Education and Humanities Research. 2018;249:55-9.

26. Srinahyanti S, Wau Y, Manurung IFU, Arjani N, editors. Influence of gadget: a positive and negative impact of smartphone usage for early child. The 2nd Annual Conference of Engineering and Implementation on Vocational Education (ACEIVE 2018); 2018; North Sumatra, Indonesia: EAI.

27. Syahidah Z, Wijayanti H. Perbedaan aktivitas fisik, screen time, dan persepsi ibu terhadap kegemukan antara balita gemuk dan non-gemuk di kota Semarang. JNC. 2017;6(1):11-8. https://doi.org/10.14710/jnc.v6i1.16886

28. Danari A, Mayulu N, Onibala F. Hubungan aktivitas fisik dengan kejadian obesitas pada anak SD di kota Manado. e-Kp. 2013;1(1):1-4. https://doi.org/10.35790/jkp.v1i1.2162

29. Roopadevi V, Sharavanti B, Aravind K. Exposure to electronic gadgets and its impact on developmental milestones among preschool children. International Jounal of Community Medicine and Public Health. 2020;7(5):1884-8. https://doi.org/10.18203/2394-6040.ijcmph20202000

30. Gusti Ayu MW, Ni Nyoman DW. The correlation between the dialogic parental guidance and the intensity of gadget utilization with the development of speaking and linguistic aspect of children at Tadika Puri early childhood education. Int $J$ Res Med Sci. 2019;7(7):2512-8. https://doi.org/10.18203/2320. 6012.ijrms20192876

31. Laini A, Fridani L, Hartati S. Influence of gadget usage and parent involvement to children's prosocial behavior. Jurnal Ilmiah Pendidikan dan Pembelajaran. 2018;2(2):174-9. http://dx.doi.org/10.23887/jipp.v2i2.15366

32. Sari TP, Mistalia AA. Pengaruh penggunaan gadget terhadap personal sosial anak usia pra sekolah di TKIT Al Mukmin. Profesi (Profesional Islam): Media Publikasi Penelitian 2016;13(2):72-8. https://doi.org/10.26576/profesi.124

33. Dalle J, Mutalib A, Saad A, Ayub M, Wahab A, AMH N. Usability Considerations Make Digital Interactive Book Potential For Inculcating Interpersonal Skills. Jurnal Teknologi (Sciences \& Engineering. 2015;01(9):1495-9. https://doi.org/10.11113/jt.v77.6837 